\title{
PERBANDINGAN KEMAMPUAN PENALARAN MELALUI MODEL PEMBELAJARAN STUDENT FACILITATOR AND EXPLANING DENGAN MODEL PEMBELAJARAN INSIDE OUTSIDE CIRCLE
}

\author{
Relawati $^{1}$, Sri Dewi ${ }^{2}$ \\ ${ }^{1,2}$ Universitas Batanghari Jambi \\ watirela908@gmail.com ${ }^{1}$
}

\begin{abstract}
Abstrak
Penelitian ini dilatarbelakangi oleh fakta yang ada di lokasi penelitian. Berdasarkan hasil observasi awal di MAN Sungai Gelam Kabupaten Muaro Jambi, fakta yang diberikan masih rendahnya kemampuan penalaran matematis siswa, terlihat dari jawaban soal yang diberikan. Hal ini disebabkan oleh guru yang lebih aktif dalam proses belajar mengajar, sedangkan siswa hanya ditempatkan sebagai penerima informasi saja. Sesuai dengan masalah yang diteliti maka metode penelitian yang digunakan adalah penelitian eksperimen karena adanya hubungan sebab akibat antara dua variabel. Penelitian ini dilaksanakan di MAN Sungai Gelam Kabupaten Muaro Jambi. Penelitian ini dilakukan pada siswa kelas XI MIA Semester Genap tahun ajaran 2019/2020. Dalam penelitian ini yang dijadikan populasi adalah seluruh siswa kelas XI MIA MAN Sungai Gelam Kabupaten Muaro Jambi. Hasil penelitian menunjukkan bahwa kemampuan penalaran matematis siswa menggunakan model pembelajaran Student Facilitator and Explaning dalam mengajarkan matematika pokok bahasan polynomial (suku banyak) pada kelas XI MIA MAN Sungai Gelam yaitu: (1) Berdasarkan hasil posttest diperoleh nilai kemampuan penalaran matematis siswa kelas sampel pada materi polynomial (suku banyak) untuk kelas eksperimen yang menggunakan model pembelajaran Student Facilitator And Explaining memperoleh rata-rata 75 dan kelas kontrol yang menggunakan model pembelajaran inside outside circle memperoleh rata-rata 67. Berdasarkan hasil akhir dapat disimpulkan bahwa kemampuan penalaran matematis siswa yang menggunakan model pembelajaran Student Facilitator and Explaning lebih tinggi dari model pembelajaran inside outside circle kelas XI MIA MAN Sungai Gelam Kabupaten Muaro Jambi.
\end{abstract}

Kata kunci: kemampuan penalaran, Student Facilitator And Explaining, inside outside circle

\begin{abstract}
The background of the research is students lack on their mathematical analysis ability that can be seen from the students' tests result. This is happened because the teachers tend to be the active ones though learning process meanwhile the students are quite passive and also act as receiver of the information only. Based on the problem, the method used in this research is experimental research because there is a relation of cause and effect to those two variables. This research was held ini MAN Sungai Gelam Kabupaten Muaro Jambi. The object of this research is the students of class XI of MIA Even Semester Year of 2019/2020. Population of the research is the entire students of XI MIA MAN Sungai Gelam Kabupaten Muaro Jambi. The result of the research shows that the students ability on mathematical analysis through Student Facilitator and Explaning learning model in learning polynomial mathematics lesson at class XI students of MIA MAN Sungai Gelam are: (1) the result of posttest from the sample students through Student Facilitator And Explaining learning model is approximately 75 and the score of class control by using inside outside circlelearning model is approximately 67. Based on the final result it can be concluded that students' mathematical analysis ability through Student Facilitator and Explaning is higher that the students who used inside outside circle learning model in the class of XI MIA MAN Sungai Gelam Kabupaten Muaro Jambi.
\end{abstract}

Keywords: Mathematical Analysis Ability, Student Facilitator and Explaning Learning model, Inside Outside Circle Learning ModeL. 


\section{PENDAHULUAN}

Dalam Undang-undang Republik Indonesia nomor 20 tahun 2003 tentang Sistem Pendidikan Nasional BAB VI pasal 14 tertulis "Jenjang pendidikan formal di Indonesia terdiri atas Pendidikan Dasar, Pendidikan Menengah (SMP dan SMA atau sederajat), dan Pendidikan Tinggi. BAB X pasal 37 tertulis "Kurikulum pendidikan untuk jenjang pendidikan dasar dan pendidikan menengah wajib memuat pendidikan matematika, pendidikan kewarganegaraan, bahasa, matematika, ilmu pengetahuan alam, ilmu pengetahuan sosial, seni dan budaya, pendidikan jasmani dan olahraga, keterampilan/kejuruan dan muatan lokal". Ini berarti setiap siswa yang berada pada jenjang Pendidikan Dasar dan Menengah wajib mengikuti pelajaran matematika.

Dilain pihak, tidak sedikit siswa yang kurang berminat dalam mengikuti pelajaran matematika. Pembelajaran matematika adalah suatu proses belajar mengajar yang dibangun oleh guru untuk mengembangkan kreativitas berfikir siswa yang dapat meningkatkan kemampuan berfikir siswa, serta dapat meningkatkan kemampuan mengkonstruksi pengetahuan baru sebagai upaya meningkatkan penguasaan yang baik terhadap materi matematika. Berdasarkan hasil observasi awal di MAN Sungai Gelam Kabupaten Muaro Jambi, fakta yang diberikan sehubungan masih rendahnya kemampuan penalaran matematis siswa, terlihat dari jawaban soal yang dikerjakan siswa dengan rata-rata jawaban di bawah 60. Dari hasil observasi juga diketahui bahwa guru matematika MAN Sungai Gelam dalam proses mengajarnya menggunakan model pembelajaran inside outside circle. Model pembelajaran inside outside circle adalah model pembelajaran dengan sistem lingkaran kecil dan lingkaran besar yang diawali dengan pembentukan kelompok besar dalam kelas yang terdiri dari kelompok lingkaran dalam dan kelompok lingkaran luar (Aris Shoimin, 2010). Model pembelajaran inside outside circle tidak cocok digunakan dalam proses belajar mengajar untuk meungukur kemampuan penalaran siswa di MAN
Sungai Gelam, terlihat dari nilai rata-rata siswa 60 pada kemampuan penalaran.

Alasan dilakukannya penelitian di MAN Sungai Gelam, sesuai dengan pengamatan peneliti pada saat melakukan pengabdian masyarakat disekolah tersebut, yaitu rendahnya pemahaman mengenai kemampuan penalaran matematis siswa terlihat dari jawaban soal-soal yang diberikan oleh guru. Dilihat dari karakteristik siswa disana, peneliti beranggapan model pembelajaran student facilitator and explaning cocok untuk diterapkan.

Model pembelajaran student facilitator and explaining merupakan rangkaian penyajian materi ajar yang diawali dengan penjelasan yang terbuka, memberikan kesempatan kepada siswa untuk menjelaskan kembali kepada rekanrekanya, dan diakhiri dengan menyampaikan semua materi kepada siswa (Huda, 2013). Model ini menjadikan siswa sebagai fasilitator dan diajak berfikir kreatif sehingga menghasilkan pertukaran informasi yang lebih mendalam dan lebih menarik serta menimbulkan rasa percaya diri pada siswa umtuk menghasilkan karya yang diperlihatkan kepada temanyatemanya. untuk mendukung pelaksanaan pembelajaran matematika di sekolah, guru harus memperhatikan pada 5 aspek pengajaran matematika (dalam NCTM, 2000), yaitu:

1) koneksi (connections)

2) penalaran (reasoning)

3) komunikasi (communications)

4) pemecahan masalah (problem solving)

5) representasi (representation)

Dalam kehidupan sehari-hari tanpa disadari kita biasanya menggunakan kemampuan berfikir kita untuk bernalar. Orang yang bernalar akan taat kepada aturan logika. Dalam logika dipelajari aturan-aturan atau patokan-patokan yang harus diperhatikan untuk berfikir dengan tepat, teliti dan teratur dalam mencapai kebenaran secara rasional.

Shurter dan Pierce (dalam Dahlan, 2004) menyatakan bahwa penalaran (reasoning) merupakan suatu proses pencapaian 
kesimpulan logis berdasarkan fakta dan sumber yang relevan, pentransformasian yang diberikan dalam urutan tertentu untuk menjangkau kesimpulan.

Menurut Suherman dan Winataputra (dalam Alamsyah, 2000), penalaran adalah proses berfikir yang dilakukan dengan suatu cara untuk menarik kesimpulan. Kesimpulan yang bersifat umum dapat ditarik dari kasus-kasus yang bersifat individual atau khusus. Tetapi dapat pula sebaliknya, dari hal yang bersifat umum menjadi kasus yang bersifat individual.

Menurut Schonfeld (dalam Sumarmo, 1987), matematika merupakan proses yang aktif, dinamik, generatif dan eksploratif. Berarti bahwa proses matematika dalam penarikan kesimpulan merupakan kegiatan yang membutuhkan pemikiran dan penalaran tingkat tinggi. Heningsen dan Stein (dalam Sumarmo, 1987) mengatakan bahwa beberapa kegiatan matematika yang merupakan berfikir dan bernalar tingkat tinggi di antaranya adalah menemukan pola, memahami struktur dan hubungan matematika, menggunakan data, merumuskan dan menyelesaikan masalah, bernalar analogis, mengestimasi, menyusun alasan rasional, menggeneralisasi, mengkomunikasikan ide matematika dan memeriksa kebenaran jawaban.

Beberapa indikator penalaran matematik (Sumarmo, 1987) dalam pembelajaran matematika antara lain, siswa dapat:

1) Menarik kesimpulan logik;

2) Memberikan penjelasan dengan model, fakta, sifat-sifat dan hubungan;

3) Memperkirakan jawaban dan proses solusi;

4) Mengunakan pola dan hubungan untuk menganalisis situasi matematik;

5) Menyusun dan menguji konjektur;

6) Merumuskan lawan contoh (counter example);

7) Mengikuti aturan inferensi; memeriksa validitas argumen;

8) Menyusun argumen yang valid;

9) Menyusun pembuktian langsung, tak langsung dan menggunakan induksi matematik.
Banyak penalaran induktif yang kita lakukan dalam kehidupan sehari-hari, misalnya adalah untuk mengetahui penyebab suatu kejadian. Dari serangkaian kejadian yang terjadi maka kita akan berusaha untuk menemukan apa penyebab atau latar belakangnya. Sehingga penalaran induktif merupakan kegiatan penarikan kesimpulan berdasarkan beberapa kemungkinan yang muncul.

Menurut Hurley (1982), penalaran induktif merupakan proses penarikan kesimpulan yang berdasarkan pada beberapa kemungkinan yang dimunculkan dari premis-premisnya. Artinya kita dapat menyimpulkan hal yang umum dari hal-hal khusus atau fakta-fakta yang dimunculkan pada premis-premisnya.

Suriasumantri (dalam Alamsyah, 2003) menyebutkan bahwa penalaran induktif merupakan suatu proses berfikir yang berupa penarikan kesimpulan yang umum atas dasar pengetahuan tentang hal-hal yang khusus. Pierce (dalam Dahlan, 2004, h.21), penalaran induksi adalah proses penalaran yang menurunkan prinsip atau aturan umum dari pengamatan hal-hal atau contoh-contoh khusus. Penalaran induktif dibagi menjadi 3 bagian yaitu generalisasi, analogi dan sebab-akibat. Menurut Sumarmo (1987):

1) Generalisasi merupakan proses penalaran yang berdasarkan pada pemeriksaan hal-hal secukupnya kemudian memperoleh kesimpulan untuk semuanya atau sebagian besar hal-hal tadi. Untuk matematika tingkat lanjutan, untuk memeriksa kebenaran hasil yang diperoleh dalam penyimpulan, maka dilakukan pemeriksaan dengan induksi matematika. Hal ini dimaksudkan untuk membuktikan apakah penyimpulan yang diperoleh berlaku untuk semua.

2) Analogi merupakan penalaran dari satu hal tertentu kepada satu hal lain yang serupa kemudian menyimpulkan apa yang benar untuk satu hal juga akan benar untuk hal lain.

Sebab-akibat, pengertian sebab-akibat hampir sama dengan penalaran generalisasi induktif hanya saja pada pengambilan 
kesimpulannya berdasarkan pada karakteristik objek yang memungkinkan terjadinya keserupaan atau ketidakserupaan objek.

Lain halnya dengan penalaran induktif, penalaran deduktif merupakan proses penarikan kesimpulan berdasarkan pada premis-premisnya secara pasti dan tidak dipengaruhi oleh faktor dari luar. Menurut Hurley (1982) bahwa penalaran deduktif artinya penarikan kesimpulan yang diturunkan secara sepenuhnya dari premispremisnya melalui aturan-aturan penyimpulan.

Menurut Suriasumantri (dalam Alamsyah, 2003), penalaran deduktif merupakan suatu proses penarikan kesimpulan dari kasus-kasus individual nyata menjadi kesimpulan yang bersifat umum. Sedangkan menurut Pierce (dalam Sumarmo, 1987) penalaran deduktif adalah proses penalaran dari pengetahuan prinsip atau pengalaman umum yang menuntun kita memperoleh kesimpulan untuk sesuatu yang khusus. Berdasarkan pendapat di atas, maka dapat disimpulkan bahwa penalaran deduktif adalah proses penarikan kesimpulan yang diturunkan sepenuhnya dari premis-premisnya dengan mengikuti aturan penarikan kesimpulan.

Penalaran deduktif menurut Barnes dan Nobel merupakan suatu metode penarikan kesimpulan yang sangat valid. Ini berarti bahwa kesimpulan yang diperoleh dengan menggunakan penalaran deduktif merupakan hasil dari kumpulan fakta atau data yang diketahui sebelumnya. Aturan penarikan kesimpulan dengan menggunakan penalaran deduktif lebih kuat. Ini berarti jika sebuah argumen valid dan anggapannya benar maka kesimpulannya akan dijamin benar. Jika dalam penarikan kesimpulan bernilai salah, maka yang salah bukan aturannya tetapi ada premis yang salah.

Menurut Matlin (1994, h.378), penalaran deduktif dibagi menjadi dua bagian yaitu conditional reasoning dan sillogisma. Menurut Matlin (1994, h.378) Conditional reasoning merupakan bagian dari berfikir yaitu mengubah informasi yang diberikan untuk memperoleh kesimpulan. Masalah yang ada dalam conditional reasoning menjelaskan kepada kita tentang adanya hubungan antara dua kondisi atau keadaan. Misalnya dinyatakan dengan hubungan if . . then ... (jika ... maka...)

Di dalam metode student facilitator and explaining siswa menerangkan dengan bagan maupun peta konsep. Dapat disimpulkan bahwa metode student facilitator and explaining adalah pembelajaran yang menjadikan siswa belajar sebagai fasilitator untuk mempresentasikan ide yang mereka buat dan diajak berpikir secara kreatif sehingga menghasilkan pertukaran informasi yang lebih mendalam dan menarik serta menimbulkan rasa percaya diri pada siswa untuk menghasilkan karya yang diperlihatkan kepada teman-temannya. Oleh karenanya, metode ini dapat meningkatkan motivasi belajar, antusias, keaktifan dan rasa senang dalam belajar siswa.

Gagasan dasar dari strategi pembelajaran ini adalah bagaimana guru menyajikan atau mendemonstrasikan materi didepan siswa lalu memberikan mereka kesempatan untuk menjelaskan kepada teman-temanya. Jadi, student facilitator and explaning merupakan rangkai penyajian materi ajar yang diawali dengan penjelasan secara terbuka, memberikan kesempatan untuk menjelaskan kembali kepada rekanrekanya, dan diakhiri dengan penyampaian seluruh materi kepada siswa (Huda, 2013: 228).

Berikut adalah sintak tahap-tahap strategi pembelajaran student facilitator and explanin adalah sebagai berikut (Huda, 2013: 228):

1) Guru menyampaikan kompetensi yang ingin di capai

2) Guru mendemonstrasikan atau menyajikan garis-garis besar materi pembelajaran

3) Guru member kesempatan kepada siswa untuk menjelaskan kepada siswa lainya, misalnya melalui bagan atau peta konsep. Hal ini bisa dilakukan secara bergiliran atau acak

4) Guru menyampaikan ide atau pendapat siswa 
5) Guru menerangkan semua materi yang disajikan saat itu

6) Penutup

Kelebihan model student facilitator and explaning, antara lain (Huda, 2013):

1) Membuat materi yang disampaikan lebih jelas dan kongkret

2)Meningkatkan daya serap siswa karena pembelejaran dilakukan dengan demonstrasi

3) Melatih siswa untuk menjadi guru, karena siswa diberi kesempatan untuk mengulangi penjelasan guru yang telah didengar

4) Memacu motivasi siswa untuk menjadi yang terbaik dalam menjelaskan materi ajar

5) Mengetahui kemampuan siswa dalam menyampaiakn idea tau gagasan

Kekurangan model student facilitator and explaning (Huda, 2013), antara lain:

1) Siswa pemalu sering kali sulit untuk mendemonstrasikan apa yang diperintahkan oleh guru

2)Tidak semua siswa memiliki kesempatan yang sama untuk melakukanya (menjelaskan kembali kepada teman-temanya karena keterbatasan waktu pembelajaran)

3) Adanya pendapat yang sama, sehingga hanya sebagian saja yang terampil

4)Tidak mudah bagi siswa untuk membuat peta konsep atau menerangkan materi ajar secara ringkas.

Sehingga dapat disimpulkan bahwa dalam proses pembelajaran matematika diperlukan metode mengajar yang tepat. Memilih metode pembelajaran harus disesuaikan dengan keadaan atau situasi kelas yang ada, serta proses kerja sama antara guru dan siswa. Dalam hal ini siswa akan terbantu dalam proses pembelajaran matematika terutama dalam penalaran matematika, sehingga tercapai hasil pembelajaran yang diinginkan. Menurut Aris (2014:87) Inside Outside Circle adalah model pembelajaran dengan sistem lingkaran kecil dan lingkaran besar yang diawali dengan pembentukan kelompok besar dalam kelas yang terdiri dari kelompok lingkaran dalam dan kelompok lingkaran luar. Anggota kelompok lingkaran luar berdiri menghadap ke dalam. Antara anggota lingkaran dalam dan luar saling berpasangan dan berhadaphadapan, di mana siswa saling membagi informasi pada saat yang bersamaan dengan pasangan yang berbeda dengan singkat dan teratur. Kemudian, siswa berada di lingkaran kecil diam di tempat, sementara siswa yang berada di lingkaran besar bergeser satu atau dua langkah searah jarum jam sehingga masing-masing siswa mendapat pasangan baru.

Aris (2014:88) Tujuan model pembelajaran Inside Outside Circle ini adalah melatih siswa belajar mandiri dan berbicara menyampaikan informasi kepada orang lain. Selain itu juga melatih kedisiplinan dan ketertiban.

Sintak tahap-tahap Model Pembelajaran Inside Outside Circle

1) Pendahuluan

Fase I: Persiapan

a) Guru melakukan apersepsi.

b) Guru menjelaskan tentang pembelajaran inside outside circle

c) Guru menyampaikan tujuan pembelajaran

d) Guru memberikan motivasi

2) Kegiatan inti

Fase 2: Pelaksanaan pembelajaran kooperatif tipe inside outside circle

a) membagi siswa menjadi beberapa kelompok yang beranggotakan 3-4 orang

b) Tiap-tiap kelompok mendapat tugas mencari informasi berdasarkan pembagian tugas dari guru.

c) Setiap kelompok belajar mandiri, mencari informasi berdasarkan tugas yang diberikan.

d) Setelah selesai, seluruh siswa berkumpul saling membaur (tidak berdasarkan kelompok).

e) Separuh kelas lalu berdiri membentuk lingkaran kecil dan menghadap keluar.

f) Separuh kelas lainnya membentuk lingkaran di luar lingkaran pertama, menghadap ke dalam.

g) Dua siswa yang berpasangan dari lingkaran kecil dan besar berbagi 
informasi. Pertukaran informasi ini bisa dilakukan oleh semua pasangan dalam waktu yang bersamaan.

h) Kemudian siswa berada dilingkaran kecil diam di tempat, sementara siswa yang berada di lingkaran besar bergeser satu atau dua langkah searah jarum jam.

i) Sekarang giliran siswa berda di lingkaran besar yang membagi informasi. Demikian seterusnya, sampai siswa selesai berbagi informasi.

j) Pergerakan baru dihentikan jika anggota kelompok lingkaran dalam dan luar sebagai pasangan asal bertemu kembali.

3) Penutup

Fase 3: Penutup

a) Dengan bimbingan guru siswa membuat simpulan dari materi yang telah didiskusikan.

b) Guru memberikan evaluasi atau latihan soal mandiri,

c) Siswa diberi PR

Kelebihan dan Kekurangan Model Pembelajaran Inside Outside Circle

Kelebihan

1) Tidak ada bahan spesifikasi yang dibutuhkan untuk strategi sehingga dengan mudah dimasukkan ke dalam pelajaran.

2) Kegiatan ini dapat membangun sifat kerja sama antar siswa

3) Mendapatkan informasi yang berbeda pada saat bersamaan.

Kekurangan

1) Membutuhkan ruang kelas yang besar

2) Terlalu lama sehingga tidak konsentrasi dan disalahgunakan untuk bergurau.

Sudah dipaparkan kekurangan dan kelebihan model pembelajaran Inside Outside Circles maka peneliti akan mengukur hipotesis dari penelitain yang dilakukan oleh peneliti. Hipotesis merupakan jawaban sementara terhadap rumusan masalah penelitian, dimana rumusan masalah penelitian telah dinyatakan dalam bentuk kalimat pertanyaan (Sugiyono, 2013: 96).

Adapun hipotesis statistik yang akan diuji adalah:

$\mathrm{H}_{0}$ : Rata-rata kemampuan penalaran matematis siswa antara yang diajar menggunakan model pembelajaran Student Facilitator And Explaning sama dengan rata-rata kemampuan pemecahan masalah dalam model pembelajaran Inside Outside Circle .

$\mathrm{H}_{1}$ : Rata-rata kemampuan penalaran matematis siswa antara yang diajar menggunakan model pembelajaran Student Facilitator And Explaning lebih tinggi dari rata-rata kemampuan pemecahan masalah dalam model pembelajaran Inside Outside Circles.

Secara matematis dapat ditulis sebagai berikut:

$$
\begin{array}{ll}
\mathrm{H}_{0} & : \mu_{1} \leq \mu_{2} \\
\mathrm{H}_{1} & : \mu_{1}>\mu_{2}
\end{array}
$$

\section{Dimana:}

$\mu_{1}:$ Adalah rata-rata kemampuan pemecahan masalah matematis siswa dengan menggunakan model pembelajaran Student Facilitator And Explaning

$\mu_{2}$ : Adalah rata-rata kemampuan pemecahan masalah matematis siswa dengan menggunakan pembelajaran Inside Outside Circle.

\section{METODE}

Sesuai dengan masalah yang diteliti maka metode penelitian yang digunakan adalah penelitian eksperimen karena adanya hubungan sebab akibat antara dua variabel. Metode yang digunakan pada penelitian ini adalah metode eksperimen.

Menurut (Sugiono, 2009: 107) metode eksperimen dapat diartikan sebagai metode penelitian yang digunakan untuk mencari pengaruh perlakuan tertentu terhadap yang lain dalam kondisi yang terkendalikan.

Penelitian eksperimen merupakan suatu penelitian yang menuntut peneliti memanipulasi dan mengendalikan satu atau lebih variabel bebas serta mengamati variabel terikat, untuk melihat perbedaan sesuai dengan manipulasi variabel bebas tersebut atau penelitian yang melihat 
hubungan sebab atau akibat kepada dua atau lebih variabel dengan memberi perlakuan lebih kepada kelompok eksperimen (Iskandar, 2009:20).

Penelitian ini dilakukan terhadap dua kelas,yaitu kelas eksperimen dan kelas kontrol. Pada kelas eksperimen dilakukan model pembelajaran student facilitator and explaning, sedangkan kelas kontrol menggunakan model pembelajaran Inside Outside Circle.

Uji hipotesis yang digunakan adalah uji kesamaan dua rata-rata. Uji ini digunakan untuk mengetahui kemampuan pemecahan masalah mana yang lebih baik antara siswa yang diajar menggunakan model pembelajaran kooperatif tipe student facilitator And explaining dengan siswa yang diajar menggunakan model Pembelajaran Inside Outside Circle. Berdasarkan hipotesis yang telah dikemukakan, maka uji satu pihak dengan hipotesis statistik:

$\mathrm{H}_{0}: \mu_{1} \leq \mu_{2}$

$\mathrm{H}_{1}: \mu_{1}>\mu_{2}$

Dimana $\mu_{1}$ dan $\mu_{2}$ adalah rata-rata hasil belajar dari dua kelompok, $\sigma_{1}$ dan $\sigma_{2}$ adalah simpangan baku dengan $\sigma_{1}=\sigma_{2}=$ $\sigma$ tetapi $\sigma$ tidak diketahui. Jika data berdistribusi normal dan homogen, menurut (Sudjana, 2007: 239) maka digunakan uji-t dengan rumus:

$$
\begin{aligned}
& \mathrm{t}_{\text {hitung }}=\frac{\bar{x}_{1}-\overline{x_{2}}}{\sqrt[s]{\frac{1}{n_{1}}+\frac{1}{n_{2}}}} \text { Dengan } S^{2} \\
& =\frac{\left(n_{1}-1\right) s_{1}^{2}+\left(n_{2}-1\right) s_{2}^{2}}{n_{1}+n_{2}-2}
\end{aligned}
$$

Dimana :

$$
\begin{array}{ll}
\mathrm{S}^{2} & =\text { Varians gabungan } \\
\mathrm{S} & =\text { Standar deviasi gabungan } \\
\bar{x}_{1} & =\text { Rata-rata kelompok eksperimen } \\
x_{2} & =\text { Rata-rata kelompok control } \\
\mathrm{s}_{1} & =\text { Standar deviasi kelompok } \\
& \text { eksperimen } \\
\mathrm{s}_{2} & =\text { Standar deviasi kelompok kontrol } \\
\mathrm{n}_{1} & =\text { Jumlah siswa kelompok } \\
& \text { eksperimen }
\end{array}
$$$$
\mathrm{n}_{2}=\text { Jumlah siswa }
$$

kelompok kontrol

Kriteria pengujiannya: terima $\mathrm{H}_{0}$ jika $\mathrm{t}<$ $\mathrm{t}_{1}-\alpha$ dimana $\mathrm{t}_{1}-\alpha$ didapat dari daftar normal baku dengan peluang $(1-\alpha)$ dan $\mathrm{dk}=\mathrm{n}_{1}+\mathrm{n}_{2}$ - 2 dengan $\alpha=0,05$, untuk harga-harga $\mathrm{t}$ yang lain $\mathrm{H}_{0}$ di tolak.

\section{HASIL PENELITIAN DAN PEMBAHASAN}

Penelitian ini dilakukan pada dua kelas sampel yaitu kelas XI MIA 2 sebagai kelas eksperimen dan XI MIA 1 sebagai kelas kontrol. Untuk mendapatkan kelas sampel ini dilakukan uji normalitas, uji homogenitas, dan uij kesamaan rata-rata terhadap populasi dengan uji barlet dan juga statistik variansi terhadap populasi. Dari uji tersebut disimpulkan analisa variansi terhadap ketiga kelas memiliki variansi yang homogen dan kemampuan penalaran matematika siswanya tidak berbeda secara signifikan pada taraf kepercayaan $95 \%$.

Pada bagian ini dideskripsikan karakteristik nilai masing-masing kelas. Adapun pengelolaan datanya secara manual, dapat dilihat pada tabel di bawah:

Tabel 1. Karakteristik Nilai Kemampuan Penalaran Matematis Siswa

\begin{tabular}{|c|c|c|}
\hline Statistik & Kelas Eksperimen & Kelas Kontrol \\
\hline Ukuran Sampel & 32 & 32 \\
\hline Rata-rata & 75 & 67 \\
\hline Nilai tertinggi & 90 & 86 \\
\hline Nilai terendah & 56 & 52 \\
\hline Simpangan Baku & 7.56 & 7.35 \\
\hline Varians & 62.820 & 53.220 \\
\hline
\end{tabular}

Jumlah siswa kelas eksperimen dan kontrol adalah 32 siswa. Rata-rata nilai kemampuan penalaran matematis siswa di kelas eksperimen adalah 75 dengan nilai tertinggi 90 dan nilai terendah 56 . Simpangan baku kelas eskperimen adalah 
7.56, sehingga varians sebesar 62.820 . Sedangkan rata-rata kemampuan penalaran matematis siswa pada kelas kontrol adalah 67 dengan nilai tertinggi 86 dan nilai terendah 52. Simpangan baku kelas kontrol adalah 7.35, sehingga varians sebesar 53.220. Sehingga dapat disimpulkan bahwa rata-rata kemampuan penalaran matematis siswa yang diajarkan menggunakan model pembelajaran inside outside circle lebih rendah dari rata-rata kemampuan penelaran matematis siswa diajarkan menggunakan model pembelajaran Student Facilitator And Explaning .Ini telihat jelas kedua kelas sampel terdapat perbedaan. Karena rata-rata kelas eksperimen lebih tinggi dari kelas kontrol.

Analisis ini bertujuan untuk mengetahui apakah terdapat perbedaan kemampuan penalaran matematis siswa antara yang menggunakan model pembelajaran Student Facilitator And Explaning dengan siswa yang menggunakan model pembelajaran inside outside circle.. Pengujian hipotesisnya dilakukan dengan menggunakan uji-t.Sebelum uji-t terlebih dahulu dilakukan uji normalitas dan uji homogenitas dari masing-masing kelas.

Uji normalitas dengan menggunakan uji barlet. Hasil uji normalitas disajikan dalam tabel 2.

Tabel 2. Hasil Uji Normalitas Kelas Sampel

\begin{tabular}{|c|c|c|c|c|}
\hline Kelas Sampel & Dk & $\mathrm{X}^{2}$ & $\begin{array}{c}\mathrm{X}_{\text {tabel }} \\
\alpha=5 \%\end{array}$ & Kesimpulan \\
\hline Eksperimen & 2 & 5,33 & 7,81 & $\begin{array}{c}\text { Sampel berasal dari populasi } \\
\text { yang berdistribusi normal }\end{array}$ \\
\hline Kontrol & 2 & 5,81 & 7,81 & $\begin{array}{c}\text { Sampel berasal dari populasi } \\
\text { yang berdistribusi normal }\end{array}$ \\
\hline
\end{tabular}

Dari tabel di atas terlihat bahwa $X^{2}<X^{2}$ tabe Imaka Ho diterima, sehingga dapatdisimpulkan bahwa sampel berasal dari populasi berdistribusi normal.
Hasil uji homogenitas varians hasil post tes hasil belajar matematika siswa dikelas eksperimen dan kelas kontrol dapat dilihat pada tabel berikut.

Tabel 3.Hasil Uji Homogenitas Kelas Sampel

\begin{tabular}{|c|c|c|c|c|c|}
\hline \multicolumn{2}{|c|}{ Varians } & \multirow[b]{2}{*}{$\begin{array}{c}\text { Taraf } \\
\text { Signifikan }\end{array}$} & \multirow[b]{2}{*}{$\mathrm{X}^{2}$ hitung } & \multirow[b]{2}{*}{$\mathrm{X}^{2}$ tabel } & \multirow[b]{2}{*}{ Keterangan } \\
\hline $\begin{array}{c}\text { Kelas } \\
\text { Eksperimen }\end{array}$ & $\begin{array}{c}\text { Kelas } \\
\text { Kontrol }\end{array}$ & & & & \\
\hline 64.730 & 54.160 & 0,05 & 1,066433 & 3.841 & $\begin{array}{l}\text { Kedua sampel } \\
\text { mempunyai varians } \\
\text { yang sama }\end{array}$ \\
\hline
\end{tabular}

Dari table di atas terlihat bahwa $\mathrm{X}^{2}{ }_{\text {hitung }}<\mathrm{X}^{2}$ tabel maka Ho diterima, artinya kedua kelompok sampel mempunyai varians yang homogen pada tingkat kepercayaan $95 \%$.

Setelah diketahui kedua sampel berdistribusi normal dan mempunyai variansi homogen, selanjutnya dilakukan uji kesamaan rata-rata dengan menggunakan uji- $\mathrm{t}$ untuk melihat apakah hipotesis penelitian diterima atau ditolak.

Dalam penelitian ini akan diuji hipotesis seperti yang telah dirumuskan dalam perumusan masalah. Hasil pengujian hipotesis yaitu:

Kriteria pengujian adalah terima $H_{0}$ jika $t_{\text {hitung }}<t_{\text {tabel }}$ untuk taraf nyata $\alpha=$ 0.05 dengan $\mathrm{dk}=n_{1}+n_{2}-2$ untuk harga $\mathrm{t}$ yang lain $H_{0}$ ditolak. Darihasil perhitungan ternyata $t_{\text {hitung }}>t_{\text {tabel }}$ yaitu 6.04> 1.67. Ini berarti $H_{0}$ ditolak. Jadi, dapat disimpulkan bahwa rata-rata kemampuan penalaran matematis siswa yang diajarkan menggunakan model pembelajaran inside outside circle lebih rendah dari rata-rata kemampuan penelaran matematis siswa diajarkan menggunakan 
Tabel 4. Hasil Uji-t Kelas Sampel

\begin{tabular}{|c|c|c|c|}
\hline Dk & $t_{\text {hitung }}$ & $t_{\text {tabel }}$ & Kesimpulan \\
\hline 66 & 6,04 & 1,67 & Tolak $\mathrm{H}_{0}$ dan terima $\mathrm{H}_{1}$ \\
\hline
\end{tabular}

Setelah dilakukan perhitungan dengan menggunakan uji-t, didapat $t_{\text {hitung }}$ sebesar 6,04 dan $t_{\text {tabel }}$ sebesar 1,67. Karena $t_{\text {hitung }}$ lebih dari $t_{\text {tabel }}$ sehingga $H_{o}$ ditolak, dengan kata lain $\mathrm{H}_{1}$ diterima dengan tingkat kepercayaan 95\%. Hal ini berarti kemampuan penalaran matematis siswa kelas eksperimen terdapat perbedaan dari kelas kontrol.

\section{SIMPULAN}

Berdasarkan pengalaman penulis selama penelitian terdapat perubahan pada hasil belajar siswa dan model pembelajaran model pembelajaran Student Facilitator And Explaning pada pokok bahasan Polinomial yang diterapkan pada proses pembelajaran dalam penelitian di MAN Sungai Gelam memberikan dampak positif. Siswa lebih bisa menemukan sendiri konsep-konsep yang ada pada matematika kemudian memahami konsep-konsep tersebut, dan lebih bertanggung jawab secara kelompok saat membuat dan menjawab pertanyaan, siswa lebih tekun dalam belajar agar dapat dan menjawab pertanyaan dengan sebaik-baiknya, serta bertanggung jawab terhadap hasil diskusi kelompoknya. Sedangkan di kelas yang menggunakan model pembelajaran inside outside circle kurang mempunyai rasa tanggung jawab terhadap kelompok, oleh sebab itu kemampuan penalaran matematis siswa yang diterapkan model ini lebih rendah dari model pembelajaran Student Facilitator And Explaning

\section{REFERENSI}

Aris, shoimin. (2014). 68 Model Pembelajaran Inovatif Dalam Kurikulum 2013. Yogyakarta: ArRuzz Media.

Alamsyah (2000) Suatu Pembelajaran untuk Meningkatkan Kemampuan
Penalaran Analogi Matematika.

Tesis. Bandung: UPI.

Dahlan, Jarnawi A. (2004)

Meningkatkan Kemampuan

Penalaran dan Pemahaman

Matematika Siswa Sekolah

Menengah Tingkat Pertama (SLTP)

melalui Pendekatan Pembelajaran

Open-Ended. Disertasi. Bandung: UPI.

Huda,Miftahul. (2013). Model-model Pengajaran dan Pembelajaran. Yogyakarta: Pustaka Belajar.

Hurley. (1982) Logic. California: Wadsworth Publishing Company.

Iskandar. (2009). Metodologi Penelitian Kualitatif . Jakarta: Gaung Persada Perss.

Matlin, W. (1994) Cognition. United State: Holt, Rinehart and Winston, Inc.

NCTM, (2000) Curriculum and Evaluation Standards for School Mathematics. United States of America: The National Council of Teachers of Mathematics, Inc.

Sudjana, Nana dan Ibrahim, (2007).Penelitian dan Penilaian Pendidikan. Bandung: Sinar Algensindo

Sugiyono. (2009). Metode Penelitian Kuantitatif, Kualitatif Dan $R \& B$. Bandung: Alfabeta.

Sugiyono. (2013). Statistik Untuk Penelitian. Bandung: Alfabeta.

Sumarmo, Utari. (1987) Kemampuan Pemahaman dan Penalaran Matematika Siswa SMA Dikaitkan dengan Kemampuan Penalaran Logik Siswa dan Beberapa Unsur Proses Belajar Mengajar. Disertasi. Bandung: UPI. 